\title{
M. R. Harrington and the Lost Mound in Hempstead County, Arkansas
}

Duncan P. McKinnon

University of Central Arkansas

Follow this and additional works at: https://scholarworks.sfasu.edu/ita

Part of the American Material Culture Commons, Archaeological Anthropology Commons, Environmental Studies Commons, Other American Studies Commons, Other Arts and Humanities Commons, Other History of Art, Architecture, and Archaeology Commons, and the United States History Commons

Tell us how this article helped you.

This Article is brought to you for free and open access by the Center for Regional Heritage Research at SFA ScholarWorks. It has been accepted for inclusion in Index of Texas Archaeology: Open Access Gray Literature from the Lone Star State by an authorized editor of SFA ScholarWorks. For more information, please contact cdsscholarworks@sfasu.edu. 


\section{R. Harrington and the Lost Mound in Hempstead County, Arkansas \\ Creative Commons License \\ (c) $($ ) $(9)$}

This work is licensed under a Creative Commons Attribution-NonCommercial 4.0 International License 


\title{
M.R. HARRINGTON AND THE LOST MOUND IN HEMPSTEAD COUNTY, ARKanSAS
}

\author{
Duncan P. McKinnon
}

\begin{abstract}
In the early months of 1916, Mark R. Harrington, under the auspices of the Museum of the American Indian, Heye Foundation, visited a mound site at the Battle Farm in Hempstead County, Arkansas. Harrington describes the location of the Hempstead County mound being three miles west of Fulton "on the brink of a low terrace of the Red river bottoms, perhaps half a mile north of that stream and a quarter of a mile east of Little River, which empties into the Red at this point." Using historical maps and archaeological site reports, this paper explores the area around the confluence of the Red and Little Rivers in search of the Lost Mound at the Battle Farm in Hempstead County. Results demonstrate that while the actual mound at the Hempstead County Battle Farm likely no longer exists on the landscape, the archaeological site 3HE413 is a likely candidate for the location of the mound site based on topographic location and the artifact assemblage recorded from the site.
\end{abstract}

\section{Introduction}

The term "Battle Place" or "Battle Mound" is typically associated with the familiar and often-mentioned Middle and Late Caddo (ca. A.D. 1200-1600) mound site located in the Great Bend region of the Red River basin in Lafayette County, Arkansas. The site was first visited and described by Clarence B. Moore in 1911 as part of his Red River explorations in Louisiana and Arkansas (Moore 1912) (Figure 1). Moore and his crew spent a few days investigating the large platform mound and the cultivated field east of the mound concentrating on "four low humps and rises of the ground that long cultivation evidently had considerably spread" (Moore 1912:566567).

In 1916, Mark R. Harrington, at that time an archaeologist with the Museum of the American Indian, Heye Foundation, also visited a site that he calls both the Mound on Battle Place and the Battle Farm west of Fulton, Arkansas, in Hempstead County (Harrington 1920:Plate 1) (Figure 2). He originally came to southwest Arkansas to continue exploring the Red River north and west of Fulton and pick-up where Clarence B. Moore had ended his Red River explorations five years earlier. Harrington describes the site he visited as being "on the brink of a low terrace of the Red river bottoms, perhaps half a mile north of that stream and a quarter of a mile east of Little river, which empties into the Red at this point" (Harrington 1920:19).

The purpose of this article is to clarify and explore. Clarification is fairly straightforward in that there are two Battle Mound sites in southwest Arkansas-one in Lafayette County and one in Hempstead County (Figure 3). The Battle Mound site in Lafayette County is recorded in the Arkansas Archeological Survey site files as 3LA1. The location of the Battle Mound site in Hempstead County is currently unknown. Based on Harrington's descriptions, the Hempstead County site he visited was located at the confluence of the Little and Red Rivers "some three miles west [of Fulton]" (Harrington 1920:19). 


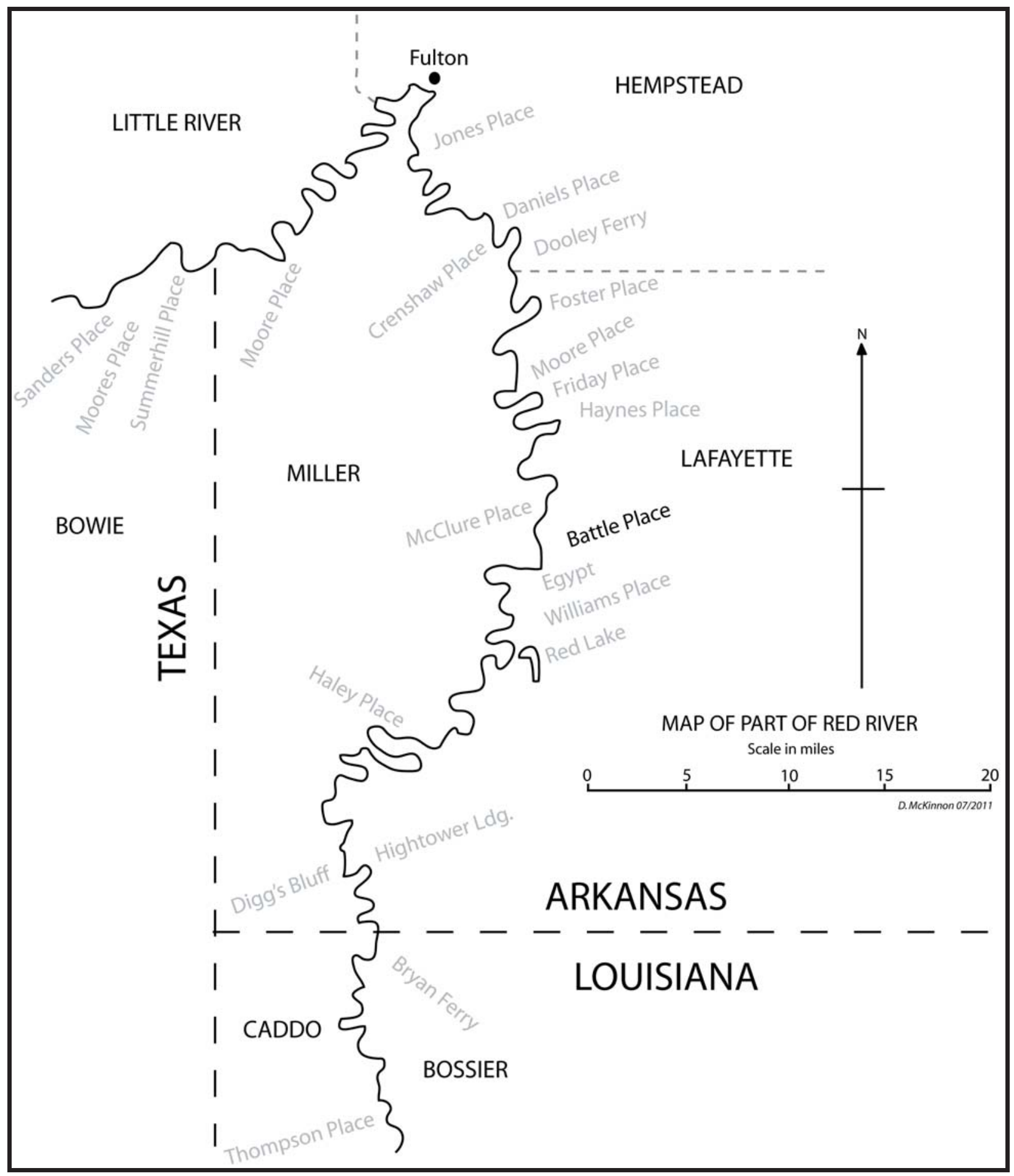

Figure 1. The location of the Lafayette County Battle Mound (3LA1) site and nearby sites (after Moore 1912:482). 


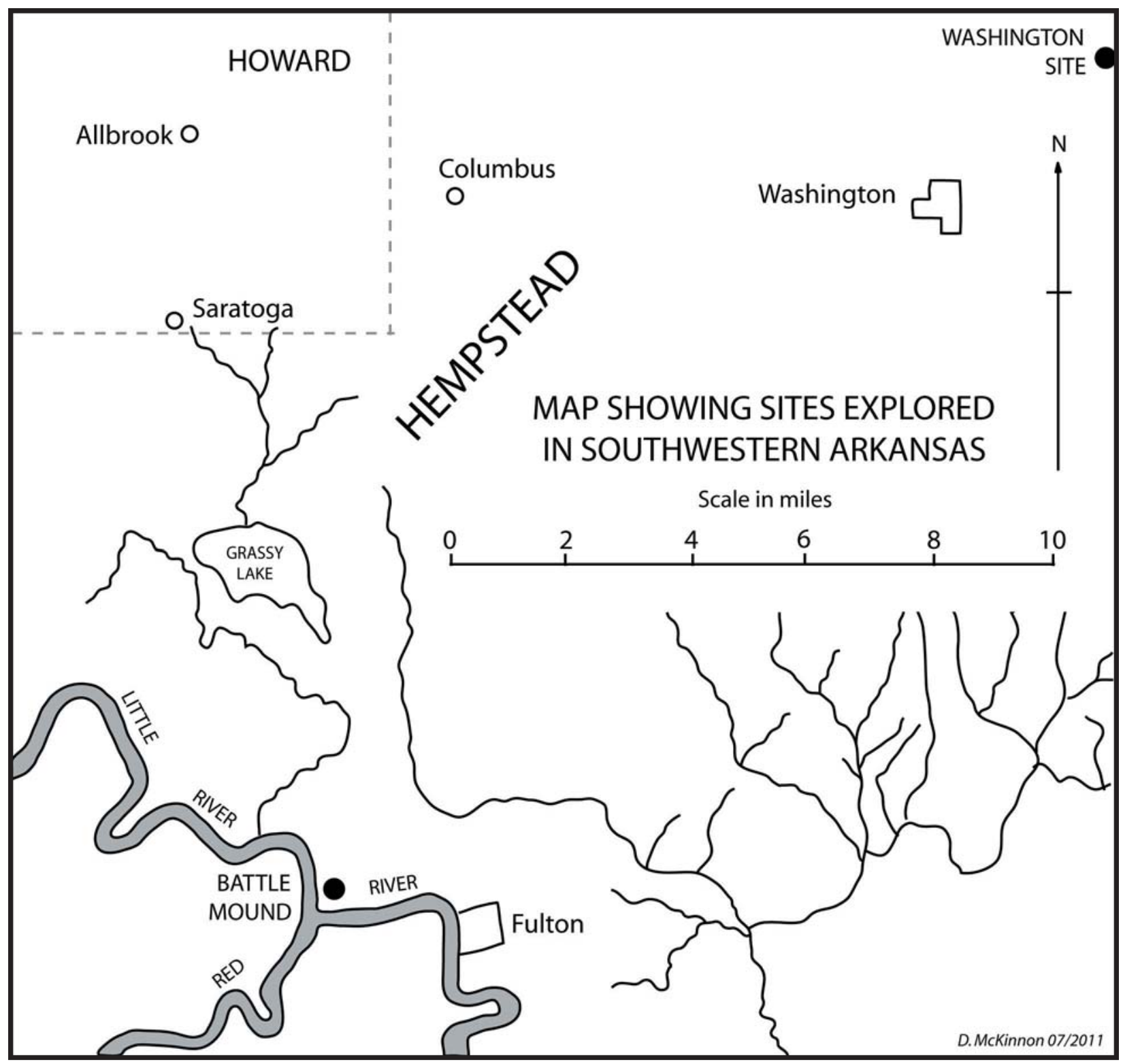

Figure 2. Hempstead County mound on the Battle Farm west of Fulton, Arkansas (after Harrington 1920:Plate 1). 


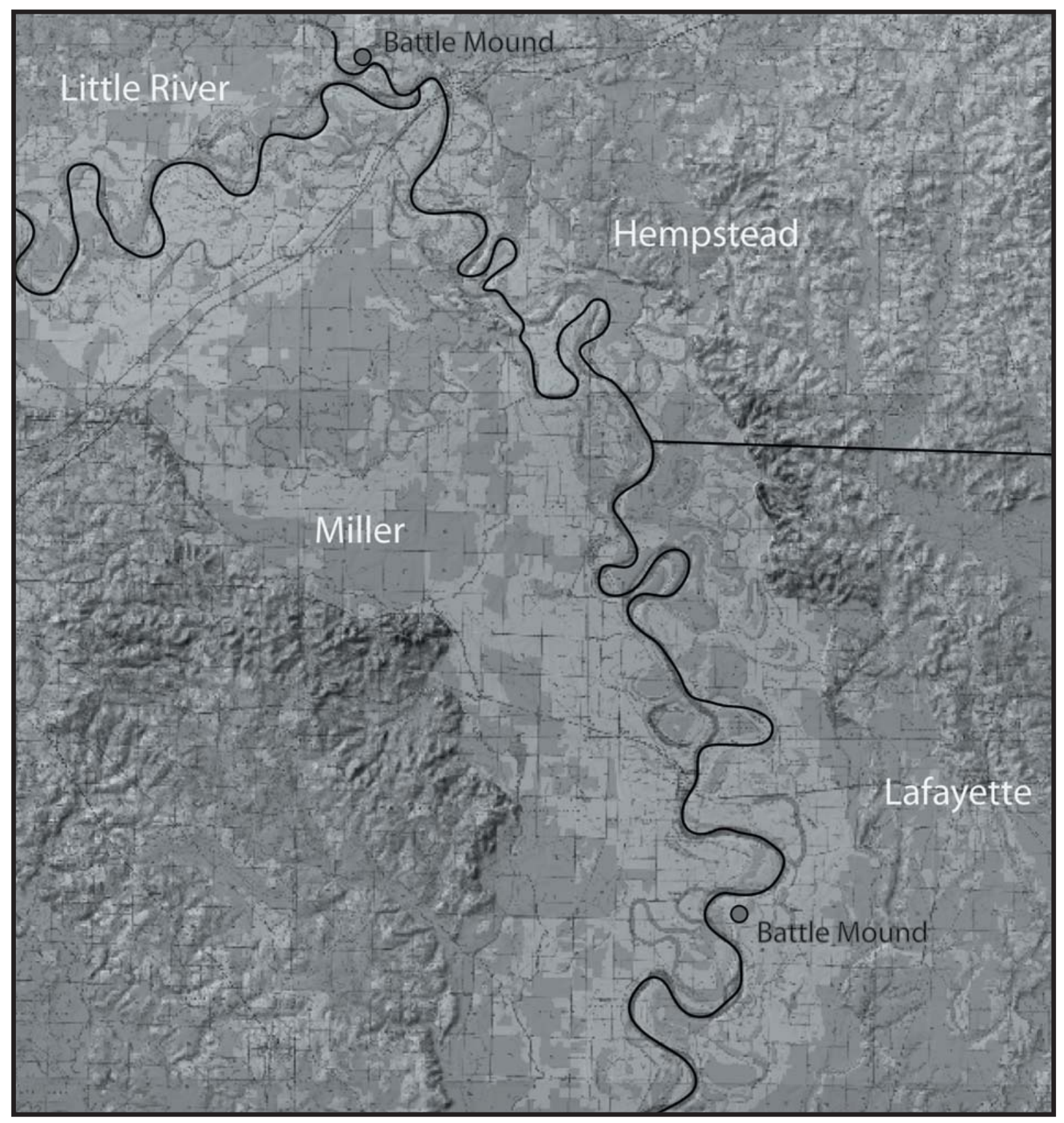

Figure 3. The relationship of Lafayette and Hempstead County Battle Mounds.

The exploration portion of this article seeks to identify possible locations of the Hempstead County Battle Mound and how those locations might relate to known archaeological sites in the area that Harrington documented. In essence, since the Hempstead County Battle Mound is not the well-known Battle Mound site in Lafayette County, what archaeological site might it represent? Using historical maps and documents, the area Harrington visited is explored to determine if the Hempstead County Battle Mound site possibly exists today, despite the destructive nature of meandering rivers and the already "dilapidated condition" that Harrington describes. 
It is worthwhile to note, as Moore mentions about the Lafayette County Battle Mound (Moore 1912:566), that the names assigned to these two sites do not represent the locations of some conflict or conflagration, but are rather named after the Battle family, early owners of the properties that Moore and Harrington visited. Given the distance between the two sites, some 37 kilometers as the crow files or about 75 kilometers following the current meandering channel of the Red River, it is appropriate (and rather interesting) to first summarize why these two sites share the same name.

\section{The Battle Family}

The Battle Family first arrived in the Americas in 1654 and secured land in both Virginia and North Carolina. The family has a long history as landowners and farmers in southeast Virginia and northeast North Carolina (Southwest Arkansas Regional Archives, Washington, Arkansas [SARA], Descendants of John and Elizabeth Battle, Vertical File [VF] 1378). James J. Battle, born on July 12, 1811 in Wake County, North Carolina, married Nancy Strickland in 1836, and the two of them slowly moved westward through Mississippi finally settling in Lafayette County, Arkansas in 1844 (Figure 4). By the 1850s, James Battle is listed on the tax rolls as the owner of land in Township 17S, Range 25W in Lafayette County - the location of the large mound associated with the Battle Mound (3LA1) site and the reason Clarence Moore refers to the site as "The Battle Place, Lafayette County, Ark." Moore adds, "the plantation does not border the river but lies about one mile back from it, near Battle Lake, a former course of [the] Red River, no doubt, which was itself the river when the aborigines occupied the site" (Moore 1912:566).

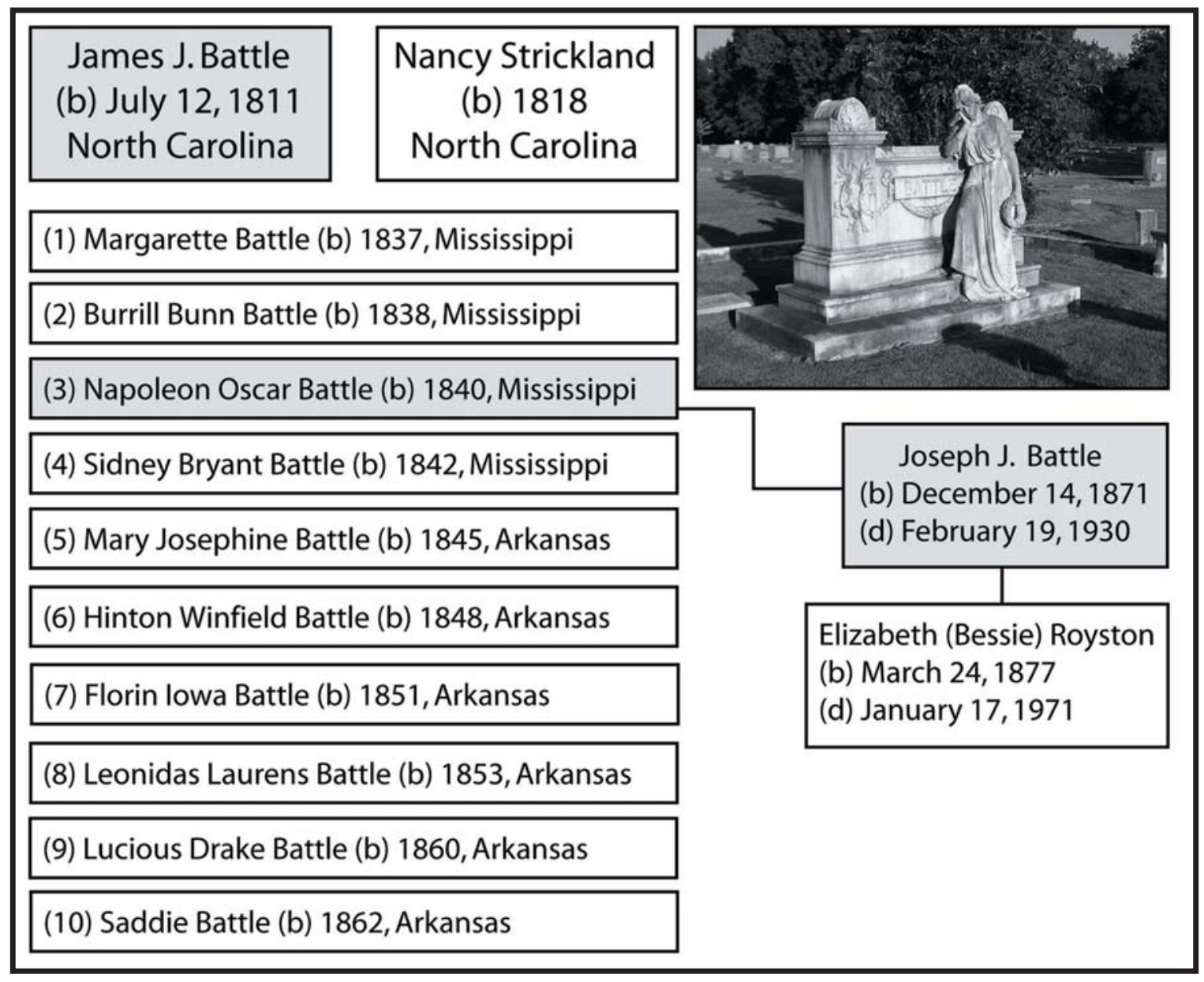

Figure 4. The Battle Family in Southwest Arkansas [SARA VF: 1378]. 
Interestingly, James Battle was not the owner of the property when Clarence Moore visited the site in 1911. Instead, Mr. Henry Moore, Jr., of Texarkana, Arkansas owned the property. Nonetheless, Moore references the (presumably well-known and respected) Battle family name to the site (in perpetuity) rather than the actual landowner at the time of his visit.

The Hempstead County Battle Mound that Mark Harrington visited five years later is named after James J. Battle's grandson, Mr. Joseph J. Battle of Fulton, Arkansas (see Figure 4). In 1907 Joseph Battle married Elizabeth (Bessie) Royston of Washington, Arkansas, granddaughter of Grandison Royston, original owner of the Royston House in Historic Washington State Park and a well-known politician in the mid-eighteenth century (see Applegate and Markus 2011). By 1914, Joseph J. Battle, a merchant and landowner, owned several plots of land west of Fulton—the "Battle Farm" that Harrington visited in 1916.

Joseph Battle did not own the tracts of land west of Fulton for very long. By 1920, the ownership had changed to the Johnson Family. It is interesting to note that Harrington visited the Battle Farm shortly after Joseph Battle purchased the land. By the time of Harrington's discussion of his explorations in his 1920 monograph, "Certain Caddo Sites in Arkansas" (Harrington 1920), the majority of land ownership at the confluence of the Little and Red Rivers in Hempstead County was no longer in the Battle Family.

\section{The Two Battle Mounds}

Both Battle Mounds are located along the Red River in southwest Arkansas. One is the familiar large mound site located in Lafayette County and the second is located in Hempstead County. The known descriptions of the structure and composition of the mounds contain some architectural similarities, although early documentation provides only cursory descriptions about the two mound sites-most notably the Hempstead County mound.

\section{Lafayette County}

Clarence B. Moore, in his 1912 monograph, "Some Aboriginal Sites on the Red River" (Moore 1912), describes a large multiplatform mound site situated along the broad alluvial floodplain of the Red River where he excavated at least five burials and thirty-five Caddo vessels. The site is located in Lafayette County, Arkansas and named after the original owner of the land, a Mr. James J. Battle (see Figure 1).

The site (3LA1) contains a large multilevel platform mound that dominates the current landscape. The large mound is composed of at least three platform levels oriented south to north and a large slope on the eastern side of the mound. It is considered the largest extant mound in the entire Caddo area and one of the largest in the southeastern United States (Perttula 1992:118; Schambach 1982a:7). Current dimensions of the mound are $200 \mathrm{~m}$ (656 feet) in length by $90 \mathrm{~m}$ (295 feet) in width, with a maximum height of $9.6 \mathrm{~m}$ (31 feet) (McKinnon 2010a:250). Directly east of the mound are two very low rises, only 0.5-1 m in height. These probably represent two of the "four low humps and rises of the ground that long cultivation evidently had considerably spread" (Moore 1912:566-567). The occupational span of the site is generally considered to be circa AD 1200 to AD 1600 (Hoffman 1970:163-164; McKinnon 2010b:13; Perttula 1992:118; Schambach 1982a:4).

Recent geophysical research reveals several off-mound anomalies attributed to prehistoric occupation, including rectangular and circular structures and associated pits and hearths, a possible large community cemetery, a possible compound fence delineating a Caddo farmstead, the remains of a borrow pit, and several midden areas (McKinnon 2009, 2010a). 
Hempstead County

Mark R. Harrington, in his 1920 monograph, briefly describes a mound at the Battle Place in Hempstead County - a short two-paragraph summary (Harrington 1920:19-20). The "Mound on Battle Place" is the first location he and his crew visited in February 1916 (see Figure 2). Harrington makes no mention of the Lafayette County Battle Mound in his monograph (Harrington 1920).

Harrington describes the Hempstead County site as located "on the brink of a low terrace of the Red river bottoms, perhaps half a mile north of that stream and a quarter of a mile east of Little river, which empties into the Red at this point" (Harrington 1920:19). The mound that Harrington recorded is a platform mound, like the large mound at the Battle Mound site in Lafayette County. However, the mound at the Hempstead County

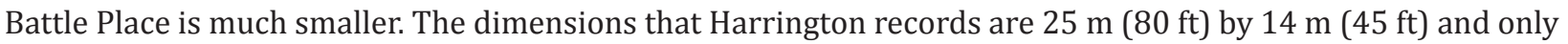
a few feet in height (Harrington 1920:19-20). He states, "The middle portion was only three or four feet high, but there seems to have been a small mound at each end of the platform, for at these points the structure, even in its present dilapidated condition, is two or three feet higher" (Harrington 1920:20).

Harrington and his crew spent several days working at and around the mound at the Battle Place with little success beyond "village refuse, and one specimen from the general digging that was really unusual[a] lizard-shaped bone awl or pin" (Harrington 1920:20) which "appears to be a lizard effigy" (Harrington 1920:227).

It's surprising that Harrington even attempted to visit this Hempstead County mound site, what he calls both the Mound on Battle Place and the Battle Farm, noting that upon arrival in Fulton his group of explorers found "that the Red river was at high flood stage, in fact, breaking through the levees into the village of Fulton as we arrived, and that the lowland, where lay many of the mounds we had hoped to explore, were completely under water and inaccessible" (Harrington 1920:15).

He and his group ultimately decided to make a change of plans and move their explorations northward away from the flooding toward sites in the Ozan Creek drainages, around Hot Springs, and the Mineral Springs and Washington sites-areas where much of the work he conducted is frequently referenced in Caddo research (see Bohannon 1962, 1966, 1973; Harrington 1920; Hoffman 1971). But before he and his crew headed north, they "learned that there was a mound on the Battle Farm, some three miles west, which remained out of water and could be worked without trouble, a mound that had yielded a pottery vessel to the desultory scratching of local collectors" (Harrington 1920:19).

\section{Exploring the Hempstead County Battle Mound}

Currently, the location of the Hempstead County Battle Mound is unknown. However, Harrington provides some descriptions that can be used, along with historical documents, to facilitate the exploration of an area of interest that can be compared with known archaeological sites to determine possible site associations.

\section{Historical Documents}

The most useful historical document utilized in this exploration is the U.S. Department of Agriculture 1916 soil survey map (Taylor and Cobb 1917). The map contains township, range and section boundaries that allow for a scanned copy to be imported into a geographic information system (GIS), properly georeferenced, and compared to current spatial datasets. Based on Harrington's description of the location of the Battle Farm, the area of interest is east of Fulton situated where the Red River turns to the south, also known as the Great Bend. In the 1916 soil survey map, the confluence of the Little and Red Rivers in is the NE corner of Section 23 (Figure 5). 


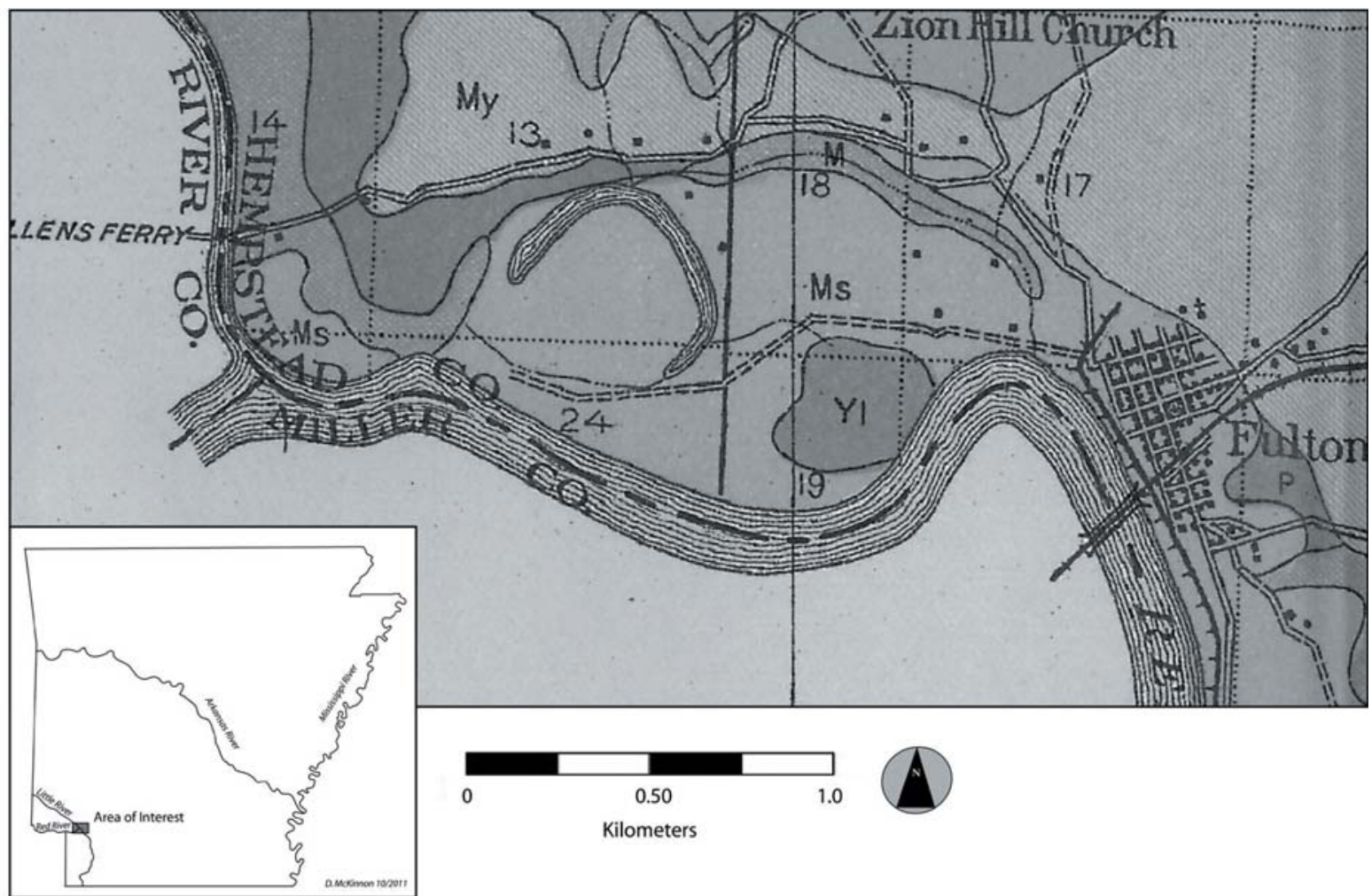

Figure 5. The 1916 soil survey map near the confluence of the Little and Red Rivers (after Taylor and Cobb 1917).

When the 1916 soil survey map is compared to a contemporary 1975 USGS photo revised USGS Quadrangle map, significant changes in the course of the rivers and the location of the confluences can be easily identified (Figure 6). In 1916, the confluence was in the northeast corner of Section 23, west of the town of Fulton. In 1975 the confluence had moved almost 2.5 kilometers east toward Fulton. Since Harrington mentions the confluence of the Little and Red in his description, understanding the location of the two rivers at the time of his visit is necessary in hopes of identifying the location of the mound he explored.

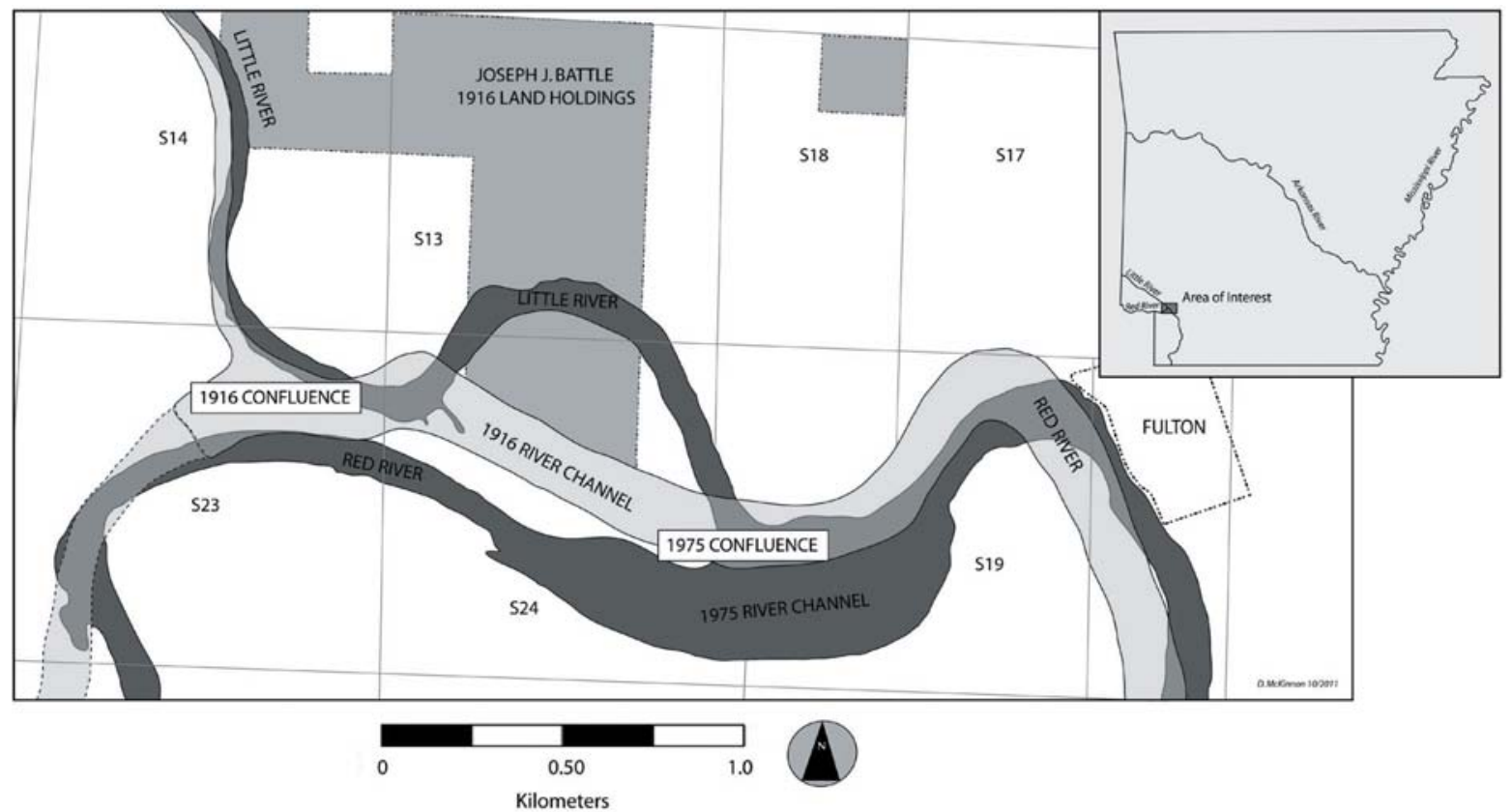

Figure 6. Comparison of 1916 river channels with 1975 river channels showing significant changes in the course of the rivers and the location of the 1916 Joseph J. Battle land holdings. 
Also necessary, in order to narrow down the broad area of interest, is an understanding of where the Battle Farm existed at this time. According to the 1914 Hempstead County Tax Rolls (Hempstead County Courthouse, Hope Arkansas [HCC] 1914: Tax Roll), Joseph J. Battle acquired tracks of land in Sections 13, 14, and 24 of Township 13 South, Range 27 West and Section 18 in Township 13 South, Range 26 West. In Section 24 , his holdings are listed as the "Fractional all 79.61 acres", since the southern portion of his holdings bordered the northern bank of the Red River at that time (see Figure 6).

\section{Archaeological Sites}

Using the combined 1916 soil survey map and Battle family land ownership as the spatial framework to the current river and landscape orientations, known archaeological sites were identified that are within those boundaries. There are five recorded sites (Hempstead County=3; Little River County=2) listed in the Arkansas Archeological Survey site database that fall within the Battle Farm property. None of them are recorded as having a mound but this is not unexpected considering that Harrington recorded the mound site as being in a "dilapidated condition" in 1916, in addition to the site likely being victim to mechanized agricultural plowing over the subsequent many years.

Each of these sites is described in turn. A succeeding section then examines each as possible candidates for Harrington's Battle Mound.

\section{$3 H E 240$}

The site 3HE240 was recorded in 1981 and is located on the upland terrace on a ridge extension or "nose" that overlooks the low flat river floodplain valley to the south and west. The site is composed of a fairly dense lithic scatter approximately 70 meters by 140 meters in size and buried just beneath the surface (Arkansas Archeological Survey, Fayetteville, Arkansas [AAS] Site File [SF] 3HE0240; New World Research 1981). A single Morhiss point (Bell 1958:58-59; Suhm et al. 1954:454) was found in the lithic assemblage, suggesting that the site dates to at least the middle to late Archaic Period (ca. 2000 B.C. - 1000 A.D.)(New World Research 1981; see also Suhm et al. 1954:454; Schambach 1982a:4). Based on the predominance of sharpening and thinning flakes and an absence of cores, the site is interpreted as a place where secondary knapping or other activities occurred, such as hide preparation or tool maintenance (AAS SF:3HE0240; New World Research 1981).

\section{$3 H E 418$}

The site 3HE418 was recorded in 2010 and is also located on an upland terrace overlooking the river floodplain. The site is defined as a light lithic scatter approximately 100 square meters in size (AAS SF:3HE0418). The artifact assemblage from this site consists of only one biface and two broken flakes, which are speculated as having been washed down slope from another area (AAS SF:3HE0418)—possibly from 3HE240 located 200 meters to the west and approximately 10 meters up slope.

\section{$3 H E 413$}

The site 3HE413 was recorded in 2009 and is situated at the base of the upland terrace on a relict natural levee formation. Site dimensions are recorded as an area 140 meters by 70 meters in size, but likely continue south beyond the original survey area (AAS SF:3HE0413). Artifact assemblage from the site totals 104 prehistoric artifacts, including 73 lithic debris that are primarily jasper and novaculite (see Scarr 2008; Trubitt 2007 for discussions on Arkansas novaculite) with a small number of rhyolite and quartz flakes, 25 ceramic sherds of varying size, and 8 fire-cracked rocks (FCRs) (AAS SF:3HE0413). Some of the ceramic sherds are shell tempered, but the majority are smoothed varieties with an unidentified temper (AAS SF:3HE0413). Shovel test work indicated that the site is likely a buried site with subplowzone deposits confined to the well-drained and slightly higher terrain natural levee landform (AAS SF:3HE0413). 
The site 3LR58 was recorded in 1982 where a Caddo burial and buried midden were eroding out of the bank of the Little River after a high water event forced the Red River to shift channels and flow into a portion of the Little River. The prehistoric component of the site contained a single burial, seven grog or bone tempered Caddo II or III (ca. AD 1200-1500) (see Perttula 1992:59; Schambach 1982a:4) vessels, and several large thick basal sherds possibly representing a Fourche Maline occupation (AAS SF:3LR0058; see Schambach 1982b, 2001, 2002 for discussion on Fourche Maline). The historic component contained a large assemblage of gun flints, window glass, a brass fish hook, several square nails of various sizes, part of an iron kettle, an olive green wine bottle fragment, some burned clay and bone and fragments of hand painted pearl ware cups-all situated directly above the prehistoric component and likely dating to the 1830s/1840s (AAS SF:3LR0058).

$3 L R 97$

The site 3LR97 was recorded in 2000 during a survey along the river beach along the west bank of the Little River during low water. (AAS SF:3LR0097). A portion of a hip socket and a skull fragment were found on the surface and no other information exists. At that time the site was recorded as being periodically inundated. It is likely that the bone fragments were secondarily deposited at this location after eroding out of a riverbank upstream, possibly from the vicinity of 3LR58.

\section{Site Evaluations and Conclusions}

It's difficult to determine with certainty at this preliminary stage which, if any, of the known sites correspond to the Battle Mound site Harrington visited in 1916. However, using the historical documents and information gathered about the archaeological sites situated within the Battle Farm, some assumptions and possibilities can be presented.

Although little is known about the two sites 3HE240 and 3HE418, what is known is that they are located on an upland terrace rather than "on the brink of a low terrace of the Red river bottoms" [emphasis added] (Harrington 1920:19) as Harrington describes. Furthermore, artifacts found on these two sites suggest that they represent lithic processing sites (although they actually may be the same site) with no ceramic sherds identified.

The two sites 3LR97 and 3LR58 are possible candidates for Harrington's Battle Mound, simply in that they both contain burial remains-although the human remains found at 3LR97 are likely from an upriver context. However, both of these sites are situated in the floodplain in a lowland area "where lay many of the mounds [he] had hoped to explore, [that] were completely under water and inaccessible" (Harrington 1920:15). Presumably, these would have been inundated by flooding and unable to be visited by Harrington and his crew.

Of the known recorded sites currently identified within the Battle Farm property, the site 3HE413 is the most promising candidate given a few simple observations. First, 3HE413 is situated on a well-drained and slightly higher terrain natural levee landform some distance from the actual channel with a maximum elevation about 40 feet higher than the river bottom elevation. Harrington specifically states that the site was located "on the brink of a low terrace of the Red river bottoms" (Harrington 1920:19), which is exactly where 3HE413 is located. Second, the artifact assemblage from the site contains numerous material items that suggest a Caddo occupational area, including the presence of ceramic sherds and several fire-cracked rocks. 
Either way, numerous Caddo ceramics and two Caddo burials have been identified on what was Joseph J. Battle's property at the confluence of the Little and Red Rivers. The mound is most likely gone or indiscernible today since a mound has not been recorded in that area and given that Harrington describes the mound as being in a "dilapidated condition" almost 100 years ago. However, based on recent surveys in the area (the foremost being the survey at 3HE413) it is very likely that a buried subplowzone site, possibly relating to the Battle Mound site that Harrington visited, is buried under meters of river deposition.

In conclusion, this article has provided clarification: Harrington's Battle Mound is not Moore's Battle Mound. This article has also explored a potential fact-the mound that Harrington visited likely no longer exists on the landscape. But the explorations do not end with this fact. Using historical maps to reconstruct the 1916 landscape and associating that landscape with the location and artifact assemblage of known archaeological sites, it is safe to state that there clearly was a Caddo settlement with an associated low multi-platform mound in the area where the Little and Red Rivers come together, discovered and recorded by Mark R. Harrington in 1916 in Hempstead County, Arkansas.

\section{Acknowledgements}

Many thanks to Peggy Lloyd, Archival Manager at the Southwest Arkansas Regional Archives (SARA), for her tremendous assistance with providing archival documents and her willingness and promptness in sharing information about the Battle Family. Drs. Kenneth Kvamme, George Sabo III, and Mary Beth Trubitt all read earlier versions of this article and provided valuable comments and suggestions. Lela Donat, Registrar at the Arkansas Archeological Survey, provided helpful assistance with access to site records and historical maps. An original version of this article was presented at the $51^{\text {st }}$ Annual Meeting of the Arkansas Archeological Society held in Ft. Smith, Arkansas.

\section{References Cited}

Applegate, Ashley R. and David M. Markus

2011 Preliminary Results of Historic Washington State Park Field School Summer 2010. Field Notes: Newsletter of the Arkansas Archeological Society 360:6-8.

Bell, Robert E.

1958 Guide to the Identification of Certain American Indian Projectile Points. Special Bulletin No. 1. Oklahoma Anthropological Society, Oklahoma City.

Bohannon, Charles F.

1962 Excavations at the Mineral Springs Site, Howard County, Oklahoma. The Arkansas Archeologist 3(10):7-9.

1966 Mineral Springs Site. In Caddoan Area Field Reports, 1962-1964 Seasons, edited by H. A. Davis, pp. 2-5. University of Arkansas Museum, Fayetteville.

1973 Excavations at the Mineral Springs Site, Howard County, Arkansas. Research Series No. 5. Arkansas Archeological Survey, Fayetteville. 


\section{References Cited (cont.)}

Harrington, Mark R.

1920 Certain Caddo Sites in Arkansas. Indian Notes and Monographs, Miscellaneous Series No. 10. Museum of the American Indian, Heye Foundation. New York.

Hoffman, Michael P.

1970 Archeological and Historical Assessment of the Red River Basin in Arkansas. In Archeological and Historical Resources of the Red River Basin, edited by Hester A. Davis, pp. 135-194. Research Series, No. 1. Arkansas Archeological Survey, Fayetteville.

1971 A Partial Archaeological Sequence from the Little River Region, Arkansas. Unpublished Ph.D. dissertation, Department of Anthropology, Harvard University, Cambridge.

New World Research

1981 A Cultural Resources Survey of the Proposed Transanadarko Pipeline System, Texas, Oklahoma, Arkansas and Louisiana (2 Volumes). Pollack, LA

McKinnon, Duncan P.

2009 Exploring Settlement Patterning at a Premier Caddo Mound Site in the Red River Great Bend Region. Southeastern Archaeology 28(2):248-258.

2010a Continuing the Research: Archaeogeophysical Investigations at the Battle Mound Site (3LA1) in Lafayette County, Arkansas. Southeastern Archaeology 29(2):250-260.

2010b Summer 1948: A Summary of Excavations at Battle Mound (3LA1), A Premier Caddo Mound Site in the Great Bend Region of the Red River. The Arkansas Archeologist 49:1-16.

Moore, Clarence B.

1912 Some Aboriginal Sites on Red River. Journal of the Academy of Natural Sciences of Philadelphia $14(4)$.

Perttula, Timothy K.

1992 "The Caddo Nation": Archaeological and Ethnohistoric Perspectives. University of Texas Press. Austin.

Scarr, Kristin D.

2008 Trace Element Studies of Arkansas Novaculite. Unpublished MA Thesis, Department of Anthropology, University of Arkansas.

Schambach, Frank F.

1982a The Archeology of the Great Bend Region in Arkansas. In Contributions to the Archeology of the Great Bend Region, edited by Frank F. Schambach and Frank Rackerby, pp. 1-11. Research Series, No. 22. Arkansas Archeological Survey, Fayetteville.

1982b An Outline of Fourche Maline Culture in Southwest Arkansas. In Arkansas Archeology in Review, edited by N.L. Trubowitz and M.D. Jeter, pp. 132-197. Research Series No. 15. Arkansas Archeological Survey, Fayetteville.

2001 Fourche Maline and its Neighbors: Observations on an Important Woodland Period Culture of the Trans-Mississippi South. The Arkansas Archeologist 40:21-50.

2002 Fourche Maline: A Woodland Period Culture of the Trans-Mississippi South. In The Woodland Southeast, edited by D.G. Anderson and R.C. Mainfort, Jr., pp. 91-112. University of Alabama Press, Tuscaloosa. 


\section{References Cited (cont.)}

Suhm, Dee Ann; Alex D. Krieger and Edward B. Jelks

1954 An Introductory Handbook of Texas Archeology. Bulletin of the Texas Archeological Society, vol. 25.

Taylor, Arthur E. and W. B. Cobb

1917 Soil Survey of Hempstead County, Arkansas. United States Department of Agriculture, Bureau of Soils. Washington, D.C.

Trubitt, Mary Beth

2007 The Organization of Novaculite Tool Production: Quarry-Workshop Debitage Comparisons. Caddo Archeology Journal 16:71-89. 